E-ISSN. 2685-7650

Vol. 2 No. 1 (2020), pp 17-27

DOI: https://doi.org/10.33366/jkn.v2i1.31

\title{
Media Sosial sebagai Budaya Baru Pembelajaran di SD Muhammadiyah 9 Malang
}

\author{
Mohammad Kamaludin \\ Program Studi Pendidikan Agama Islam, Universitas Muhammadiyah Malang \\ Email: kamalmerah@yahoo.co.id
}

\begin{abstract}
This study tries to find answers to the application of social media as a new form of culture in learning. SD Muhammadiyah 9 Malang which is the object of research has characteristics that are in line with the research theme. SD Muhammadiyah 9 Malang has implemented social media in the last few years. In the results of this study found many interesting things that can be said as a form of habit which in social language is called culture. In addition, the impact of this new learning culture is very positive. This means it is different from the previous community's understanding that social media must be kept away from children because it can interfere with learning. From the application of social media for learning, SD Muhammadiyah 9 Malang can encourage students to be creative, innovative and able to adapt critically to the negative effects of social media. Although there are some notes that need attention or just tips and tricks from teachers or teachers to avoid the negative impact of social media.
\end{abstract}

Keywords: Social media, culture, learning

\begin{abstract}
Abstrak: Penelitian ini mencoba mencari jawaban atas penerapan media sosial sebagai bentuk budaya baru dalam pembelajaran. SD Muhammadiyah 9 Malang yang menjadi objek penelitian mempunyai karakteristik yang sesuai dengan tema penelitian. Sebab di lokasi penelitian ini sudah menerapkan media sosial dalam beberapa tahun terakhir. Tidak mengherankan dalam hasil penelitian ini ditemukan banyak hal menarik yang bisa dikatakan sebagai bentuk kebiasaan yang dalam bahasa sosial disebut sebagai budaya. Di samping itu ternyata dampak yang ditimbulkan dari budaya baru pembelajaran ini sangat positif. Artinya berbeda dari pemahaman masyarakat sebelumnya yang menganggap media sosial harus dijauhkan dari anak-anak karena bisa menganggu pembelajaran. Dari penerapan media sosial untuk pembelajaran ini pula SD Muhammadiyah 9 bisa mendorong siswanya untuk kreatif, inovatif, dan mampu beradaptasi secara kritis meghadapi serangkaian efek negatif media sosial. Meskipun ada beberapa catatan yang perlu diperhatikan atau sekedar tip dan trik dari para pengajar atau guru untuk menghindari dampak negatif media sosial.
\end{abstract}

Kata kunci: Media sosial, budaya, pembelajaran

\section{Pendahuluan}

Seiring perkembangan zaman, berkembang pula ilmu-ilmu yang menghasilkan teknologiteknologi yang memudahkan dan membantu kegiatan masyarakat saat ini. Hasil-hasil teknologi ini bisa digunakan dalam segala hal khususnya untuk peningkatan pendidikan di dunia.

Perkembangan ilmu pengetahuan dan teknologi ini semakin mendorong upaya-upaya pembaharuan dalam pemanfaatan hasil-hasil teknologi dalam proses belajar. Yang mana dalam proses belajar mengajar alat-alat teknologi ini sudah menjadi komponen penting dalam pendidikan untuk mempermudah dan mampu menciptakan suasana belajar yang kondusif. Secara lebih khusus, media dalam proses belajar mengajar cenderung diartikan sebagai alat-alat grafis, fotografi, atau elektronis untuk menangkap, memproses, dan menyusun kembali informasi visual atau verbal (Arsyad, 2007).

Sedangkan belajar adalah proses perubahan untuk menjadi lebih baik. Proses belajar mengajar dapat berhasil jika para siswa mempunyai gairah untuk mengikuti pelajaran dan tidak merasa kesulitan dalam mengejar pelajaran. Selain itu para siswa dapat termotivasi untuk mengkaji lebih 


\section{Jurnal Komunikasi Nusantara}

\section{E-ISSN. 2685-7650}

Vol. 2 No. 1 (2020), pp 17-27

DOI: https://doi.org/10.33366/jkn.v2i1.31

dalam lagi dan memiliki dan meneliti pelajaran yang telah disampaikan. Adapun indikator belajar antara lain; pertama, siswa dapat mengerti dan memahami pelajaran yang sudah disampaikan, kedua, siswa dapat membuahkan perubahan signifikan pada perilaku siswa, ketiga, siswa dapat memperluas wawasan dan pengalaman siswa.

Penggunaan media dalam proses belajar sangat membantu pentransferan ilmu dari guru kepada siswa. Hal ini sesuai dengan pendapat Hamalik bahwa pemakaian media pembelajaran dalam proses belajar mengajar dapat membangkitkan keinginan dan minat yang baru, membangkitkan motivasi dan rangsangan kegiatan belajar, dan bahkan membawa pengaruh-pengaruh psikologi terhadap siswa (Hamalik, 2005). Sedangkan dalam penggunaan media didapatkan indikator seperti, dapat memotivasi minat dan tindakan siswa, mampu menyajikan informasi yang dibutuhkan, dan mampu memberi instruksi pada siswa.

Akhir-akhir ini media sosial, seperti whatsapp, instagram, facebook, dan media lain yang serupa, menjadi cara baru bagi siapa pun termasuk guru untuk menyebarkan informasi. Kemudahan akses pada media-media itu menyebabkan persebaran informasi atau apa pun yang berkenaan dengannya semakin cepat dan kadang tak terkendali. Belum begitu jelas apakah informasi yang didapatkan oleh mereka yang menerima bisa dipertanggungjawabkan atau tidak (Zendrato, 2016). Perlu penelaahan lebih lanjut atas hal itu. Berkaca dari sini penelitian terhadap pembiasaan (budaya) baru dalam memperlakukan media sosial menjadi urgen dilaksanakan.

\section{Media Sosial sebagai Alat Pembelajaran}

Perkembangan media terutama media sosial akhir-akhir ini luar bisa masif. Hampir semua bidang telah dimasuki oleh media sosial sebagai perantara berkomunikasi manusia, begitu pula di bidang pendidikan. Anthony Giddens mengumpamakan keadaan seperti ini sebagai 'juggernuts' yang siap kapan saja melibas kondisi yang tidak mau berubah.

Istilah media berasal dari bahasa latin 'medius' yang berarti tengah, perantara atau pengantar. Gerlach dan Ely (1971) mengatakan bahwa bila dipahami media secara garis besar adalah manusia, materi, atau kejadian yang membangun kondisi yang membuat orang lain mampu memperolah pengetahuan, keterampilan, atau sikap. Jadi dalam pengertian media sebagai alat pembelajaran, guru, buku teks, dan lingkungan sekolah adalah media. Lebih khusus lagi media dalam hal ini cenderung diartikan sebagai alat-alat grafis, fotografis, atau elektronis yang menangkap, memproses, dan menyusun kembali informasi visual dan verbal.

Di sisi lain AECT (Association of Education and Communication Technology, 1977) membatasi media sebagai segala bentuk dan saluran yang digunakan untuk menyampaikan pesan atau informasi. Biasanya istilah ini diganti dengan 'mediator' yang menurut Fleming (1987) adalah penyebab atau alat yang ikut campur dalam dua pihak dan mendamaikannya. Sehingga istilah mediator media menunjukkan fungsi atau perannya untuk mengatur hubungan efektif antara dua pihak utama dalam proses belajar -siswa dan isi pelajaran. Mediator dapat pula mencerminkan pengertian bahwa setiap sistem pembelajaran yang melakukan peran mediasi, mulai dari guru sampai kepada peralatan yang paling canggih bisa disebut media. Jadi media merupakan alat yang menyampaikan atau mengantarkan pesan-pesan pembalajaran (Arsyad, 2016).

\section{Media Sosial sebagai Budaya Pembelajaran}

Pendidikan dikatakan sebagai alat utama untuk mentransformasikan kebudayaan atau memperbaiki sistem sosial (Thut \& Adams, 2005), tidaklah salah jika secara terus-menerus perlu disosialisasikan. Cara yang dipergunakan bisa bermacam-macam. Dari yang paling sederhana 


\section{Jurnal Komunikasi Nusantara}

\section{E-ISSN. 2685-7650}

Vol. 2 No. 1 (2020), pp 17-27

DOI: https://doi.org/10.33366/jkn.v2i1.31

misalnya dengan bentuk tutur berantai hingga yang paling kompleks dengan memanfaatkan teknologi informasi.

Pada masa lampau informasi yang disampaikan kepada orang lain melalui udara dengan media hewan seperti burung merpati yang membawa sepucuk pesan dari tempat yang jauh dan tak terjangkau. Meskipun pesan itu singkat namun penantian berita merupakan hal yang lumrah bagi mereka yang sedang menunggu kabar atau informasi terbaru. Penting bagi masyarakat saat itu untuk memeroleh informasi agar perubahan segera dilakukan. Hari per hari atau bulan per bulan seolah tidak menyurutkan keinginan mereka mendapatkan kabar. Penggunaan media merpati sebagai perantara pesan telah membudaya dalam masyarakat. Jika dilihat ada banyak pertimbangan penggunaan merpati sebagai penyampai pesan. Pertama, dari segi jangkauan merpati dapat diandalkan karena daerahdaerah yang luas dan terpencil akan mampu ditaklukkannya, yang belum tentu manusia bisa menjangkaunya. Kedua, efektivitas dan efisiensi waktu dan keekonomian merpati bisa mengalahkan hewan yang lain. artinya biaya perawatan yang dikeluarkan tidak terlalu banyak. Ketiga, tingkat kepercayaan terhadap merpati cukup tinggi, yang berarti apa pun pesan yang dibawa oleh merpati pasti sampai ke tujuan dan kembali tepat di tempat semula. Karena merpati secara biologis memiliki insting mengenal wilayah yang cukup luas.

Belajar dari pesan merpati itu, akhirnya manusia mulai mengembangkan diri untuk bisa melakukan hal yang sama atau bahkan lebih baik. Muncul media pos surat sebagai pengganti merpati. Pos surat mempunyai sejarah panjang sebelum datangnya era digitalisasi dan teknologi informasi. Penggunaan media pos surat hanya sedikit merubah cara merpati, yang dulunya merpati hanya membawa sepucuk surat kini pos surat bisa membawa lebih banyak (informasi). Artinya sepucuk surat merpati hanya membawa pesan singkat yang nantinya menjadi bahan data bagi penerimanya selanjutnya untuk dibalas dengan cara yang sama, sedangkan era pos surat data yang diterima bisa lebih banyak karena kurir pembawanya bisa menmapung kapasitas yang memadai bahkan untuk barang dan uang sekali pun.

Penggunaan alat komputer menuntut penggunanya belajar beradaptasi pada perubahan. Adaptasi memerlukan waktu sedangkan sistem komputerisasi menuntut kecepatan. Jika pengetahuan tidak memadai maka pengguna akan tertinggal. Pengetahuan dapat diperoleh paling mudah di bidang pendidikan, dari sini bidang pendidikan menemukan relevansinya. Pengajaran dan pembelajaran bersinergi membentuk jalinan pola yang saling membutuhkan.

Sistem komputerisasi juga memerlukan kondisi lingkungan yang mendukung berkembangnya sistem tersebut. Tanpa dukungan lingkungan yang memadai mustahil sebuah sistem dapat mudah menyebar ke setiap organisasi terkecil seperti individu manusia. Pendidikan adalah lahan bagi tumbuh-subur perkembangan komputerisasi di masyarakat. Penyampaian materi belajar pun merujuk pada pola yang sama dengan sistem komputerisasi. Sehingga di dunia pendidikan komputer bukan menjadi barang asing lagi. Setelah teknologi berkembang pesat, dunia informasi mengikuti di belakangnya. Awalnya informasi yang diperoleh hanya melalui media cetak, buku bacaan secara manual atau offline, kini terhubung dengan bantuan komputer dengan sambungan kabel internet atau online.

\section{Penggunaan Media Sosial dalam Pembelajaran}

Hakikat Pembelajaran Pembelajaran merupakan istilah terjemahan dari kata instruction, yang kadang-kadang diartikan sama dengan pengajaran, meskipun dasarnya berbeda. Istilah pengajaran berkaitan dengan konteks interaksi guru-siswa di dalam kelas. Istilah pembelajaran lebih menekankan pada kegiatan belajar siswa melalui usaha yang terencana dengan memanipulasi sumber-sumber belajar agar terjadi proses belajar. Maknanya bahwa istilah pembelajaran lebih luas dibandingkan 


\section{Jurnal Komunikasi Nusantara}

E-ISSN. 2685-7650

Vol. 2 No. 1 (2020), pp 17-27

DOI: https://doi.org/10.33366/jkn.v2i1.31

dengan kata pengajaran yang hanya menekankan pada aspek interaksi guru-siswa saja. Secara terminologis, Işman, Çağlar, Dabaj, dan Ersözlü (2005) mengutip teori Knirk \& Gustafson menyatakan bahwa pembelajaran merupakan kegiatan yang dirancang oleh guru untuk membantu siswa mempelajari suatu kemampuan dan atau nilai yang baru dalam suatu proses yang sistematis melalui tahap rancangan, pelaksanaan, dan evaluasi kegiatan belajar mengajar. Definisi ini lebih menekankan adanya langkah sistematis yang dilakukan oleh guru dalam mengembangkan instructional design (ID), yang mencakup tiga tahapan, yaitu tahap desain, tahap pelaksanaan dan tahap evaluasi. Sementara itu Clark \& Mayer (2008: 7) menyatakan bahwa hakikat pembelajaran mencakup apa yang dilakukan oleh guru dalam rangka membelajarkan siswanya. Lebih lanjut dijelaskan bahwa termasuk dalam cakupan pengertian pembelajaran ini adalah komponen guru, model/metode, strategi, permainan yang mendidik, buku, proyek penelitian dan penyampaian pembelajaran berbasis Web. Rumusan legal formal tentang pembelajaran dapat ditemukan dalam Pasal 1 angka (4) Permendikbud No. 49 Tahun 2014 tentang Standar Nasional Pendidikan Nasional, yang menyatakan bahwa Pembelajaran merupakan proses interaksi siswa dengan guru dan sumber belajar pada suatu lingkungan belajar.

Pada periode saat ini setelah era diperkenalkannya komputer pada masyarakat, proses pembelajaran sedikit bergeser ke arah pemggunaan komputer sebagai pendukung utama pembelajaran. Desain pembelajaran mulai memanfaatkan kecanggihan komputer untuk memudahkan pemahaman siswa di kelas. Bukan saja di kelas tapi di banyak kesempatan pembelajaran penggunaan desain-desain menarik bermanfaat menambah pengetahuan. Desain power point slide misalnya ; dari waktu ke waktu mengalami perubahan dan perbaikan dari banyak sisi, dari slide pasif ke slide aktif yang interaktif mempermudah kondisi belajar bagi siapa pun. Hingga yang terbaru lahirnya media sosial seperti WhatsApp, Instagram, Facebook atau Youtube yang didesain sangat interaktif. Siaran video streaming dapat dinikmati oleh pengguna hanya melalui satu gawai sudah terinstall dengan aplikasi yang diinginkan.

\section{Metode Penelitian}

Jenis penelitian ini merupakan penelitian etnografi yaitu studi tentang kelompok kebudayaan atau kelompok sosial yang utuh (atau satu individu atau beberapa individu dalam kelompok tersebut) berdasarkan terutama pada pengamatan dan kehadiran sanag peneliti di lapangan dalam waktu yang lama. Seorang etnografer mendengarkan dan merekam suara dari para informan dengan tujuan untuk menghasilkan gambaran atau potret kebudayaan (Creswell, 2015).

Sedangkan untuk sumber data peneliti menggunakan sumber data primer dari hasil wawancara dan observasi. Dan sumber data sekunder yaitu media sosial yang berkaitan dengan tema yang menjadi objek penelitian (Furhan, 2000: 34). Data yang terkumpul selanjutnya dianalisis secara tajam dan terukur dari hasil data primer dan sekunder. Analisis dilakukan secara induktif, dan deskriptif guna mendapatkan hasil yang diinginkan dan kesimpulan yang memadai (Moleong, 2017).

\section{Hasil dan Pembahasan \\ Penyajian Data}

Salah satu metode pembelajaran melalui program-program SD Muhammadiyah 9 yang sudah lama dilakukan adalah pemanfaatan media sosial. Setiap program sekolah sebisa mungkin ditayangkan di media sosial, seperti youtube, twitter, whatsapp, atau facebook.

Menurut para guru media sosial bisa menjadi metode mengukur perkembangan siswa. Penayangan program di media sosial dilakukan oleh para guru yang berkeinginan mendidik siswanya 


\section{Jurnal Komunikasi Nusantara}

\section{E-ISSN. 2685-7650}

Vol. 2 No. 1 (2020), pp 17-27

DOI: https://doi.org/10.33366/jkn.v2i1.31

untuk mengetahui diri mereka sendiri. Dalam arti siswa tahu jika dirinya sedang disorot di media sehingga mereka berusaha tampil sebaik-baiknya. Meskipun sulit bagi para siswa untuk tampil napa adanya karena mereka harus mau diatur sedemikian rupa namun ketidaknaturalan ini menurut para guru adalah hal yang positif. Siswa akan terbiasa siap-sedia kapan pun menunjukkan kemampuan terbaiknya. Sebagai contoh pada penayangan "penerapan pendidikan karakter" di bawah ini:

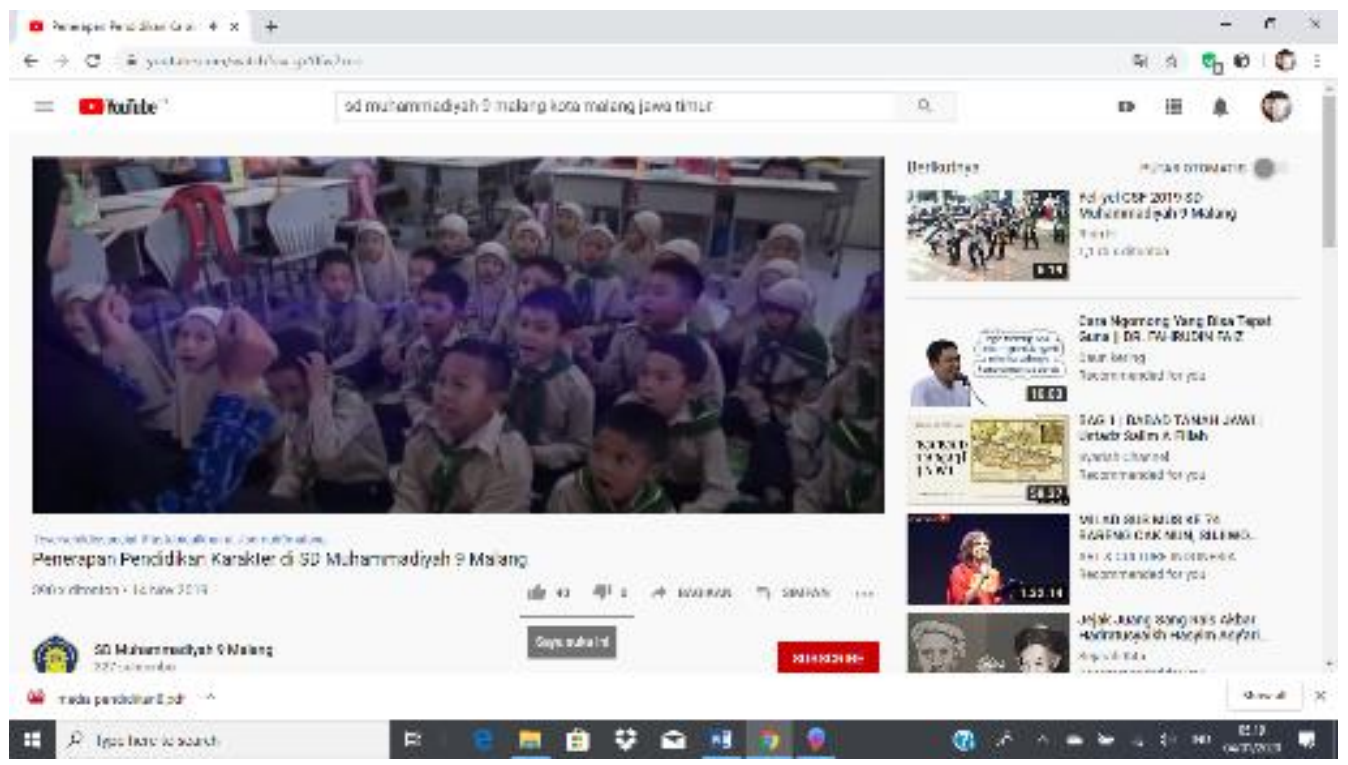

Gambar 1. Youtube Penerapan Pendidikan Karakter

Siswa nampak harus bersedia melihat ke depan dengan perhatian tertuju pada seorang guru. Mereka diarahkan untuk tetap fokus selama proses pemgambilan gambar dan guru memberikan contoh agar terlihat tidak sengaja direkam. Durasi waktu tidak diperhitungkan terlalu ketat namun jika terjadi kesalahan konsekuensinya harus diulang dari awal. Dengan begitu siswa akan secara aktif dengan sendirinya berusaha serius walaupun guru tidak pernah menyuruhnya. Dalam kesempatan itu pula proses pembelajaran sedang dimasukkan (proses internalisasi) oleh guru ke siswa. Tanpa sadar siswa menerima pengetahuan yang disampaikan oleh guru dengan mudah karena mereka sudah mempersiapkan diri secara serius pada momen sebelumnya. Ketidakterdugaan menerima pembelajaran ini merupakan harapan guru agar siswa mudah mengingat pengetahuan yang tersampaikan. Jikalau pada saat yang lain mereka lupa akan proses pembelajaran tersebut cara lain yang bisa ditempuh adalah memutar kembali rekaman yang sudah dibagikan di media sosial yang ada. 


\section{Jurnal Komunikasi Nusantara}

\section{E-ISSN. 2685-7650}

Vol. 2 No. 1 (2020), pp 17-27

DOI: https://doi.org/10.33366/jkn.v2i1.31

Pada video berdurasi 15 menit di bawah ini menunjukkan sebuah kegiatan ajang unjuk kebolehan yang dilakukan setiap kelas.

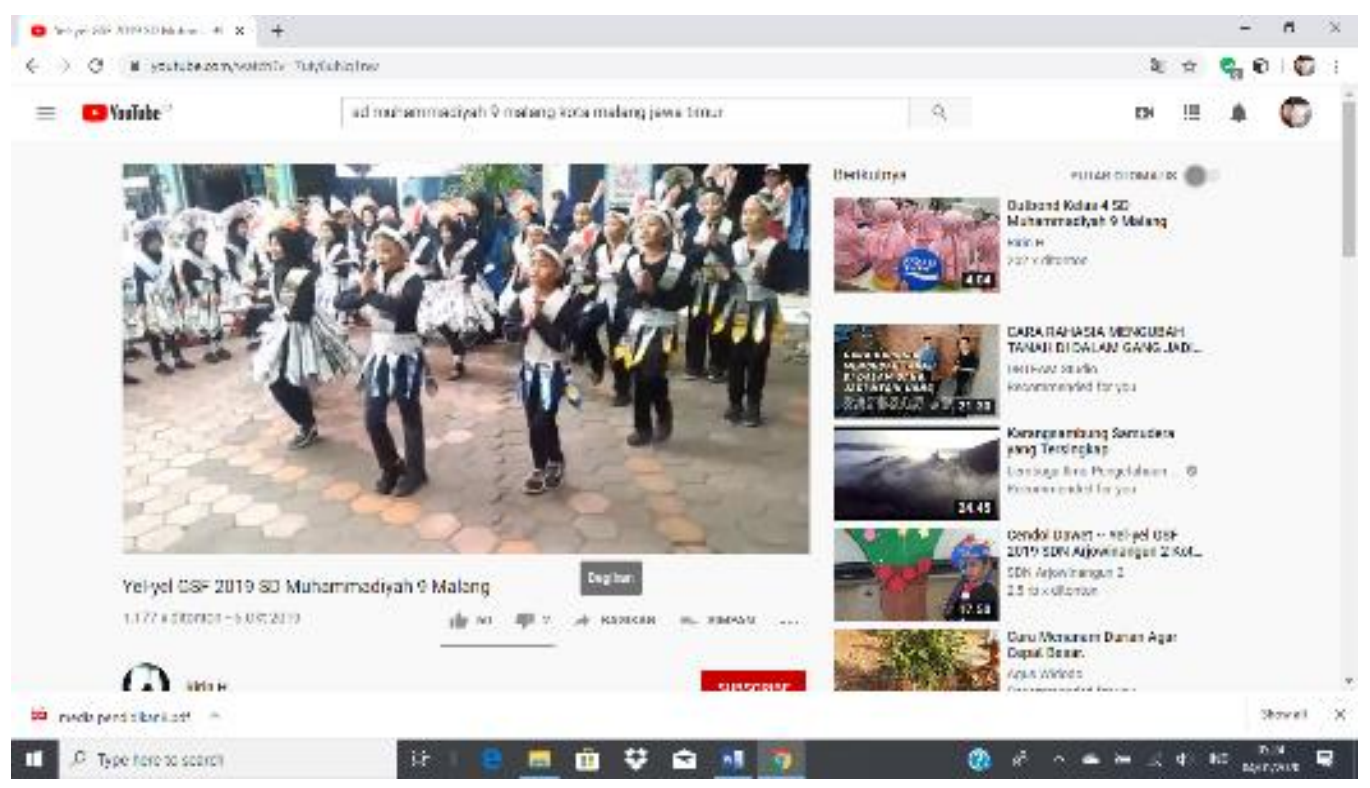

Gambar 2. Youtube Yel-Yel GSF 2019

Masing-masing kelas menampilkan pertunjukan terbaiknya sesuai dengan kreatifitas dan inovasi yang ada dalam diri siswa. Guru hanya mengarahkan dari kejauhan sambil mengamati masing-masing siswa anak didiknya. Melalui pertunjukan ini setiap langkah dan gerak-gerik, atau bahkan mimik wajah akan terlihat jelas. Meskipun hanya sekedar tarian-tarian sederhana berupa yelyel, potensi yang ada dalam diri siswa akan dievaluasi dan dinilai. Selanjutnya hasil evaluasi bisa digunakan sebagai ukuran untuk menetapkan atau merancang proses pembelajaran lainnya. Bisa pula menurut pendapat seorang guru kelas, dari penampilan seorang siswa bakat yang terpendam bisa diarahkan menuju tahap yang lebih tinggi. Seperti dilatih tersendiri dan diikutsertakan dalam lombalomba tingkat yang lebih luas. Inilah salah satu cara SD Muhammadiyah 9 mencari bibit-bibit unggul masa depan.

Sebuah contoh menarik adalah seorang siswa bernama Haidar Ramadhan yang awalnya tidak dikenal sama sekali. Seorang guru agama hanya menyuruhnya menjadi imam sholat dhuhur berjamaah, karena program sholat dhuhur merupakan salah satu program pembelajaran bagi siswa SD Muhammadiyah 9. Setiap siswa secara bergiliran mempunyai kesempatan yang sama sebagai imam shalat berjamaah. Kemudian guru menemukan kemampuan siswa Haidar ini dan berinisiatif mempublikasikan melalui media sosial. Meskipun hanya sedikit yang menonton, tetapi bukan itu tujuannya. 


\section{Jurnal Komunikasi Nusantara}

E-ISSN. 2685-7650

Vol. 2 No. 1 (2020), pp 17-27

DOI: https://doi.org/10.33366/jkn.v2i1.31

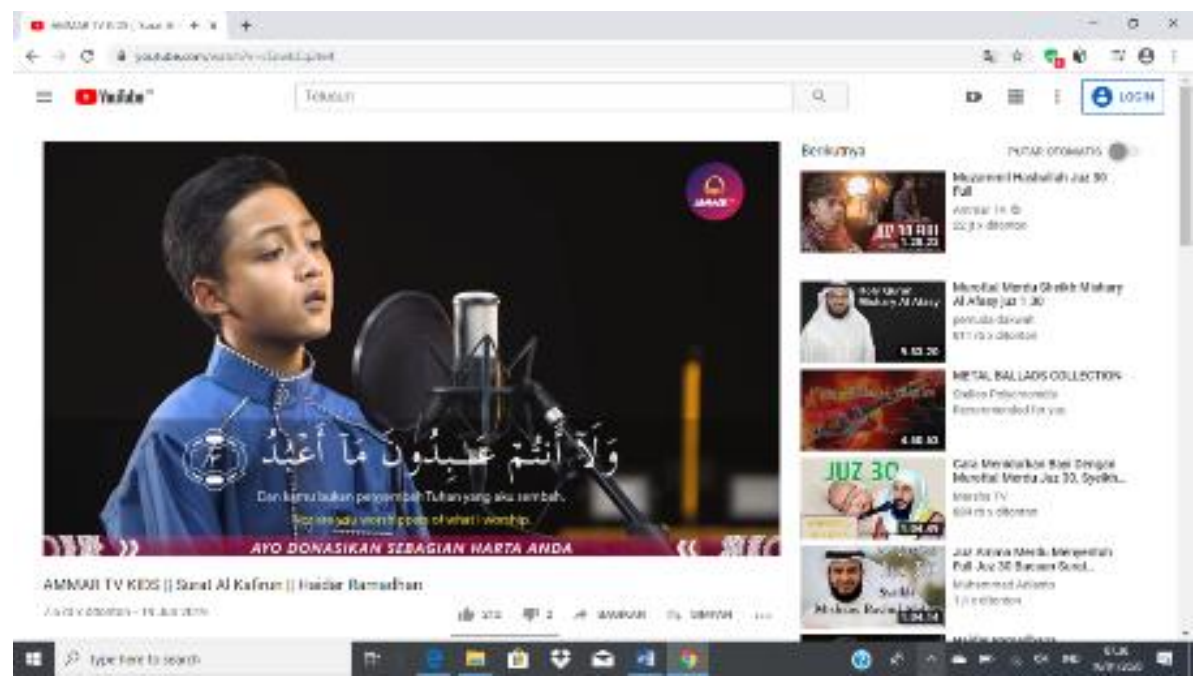

Gambar 3. Youtube Ammar TV - Haidar Ramadhan

Nama Haidar dikenal sedikit saja oleh masyarakat sudah cukup bagi sekolah. Dan ternyata sambutan masyarakat luar biasa, karena Haidar mempunyai suara yang khas dan menarik bagi kalangan di media sosial. Penonton di media sosial atau diistilahkan dengan follower yang sebelumnya hanya sekitar seribuan naik drastis menjadi ratusan ribu. Ini bisa terlihat dari tayangan video ketika Haidar menjadi salah satu imam di sebuah masjid dan direkam secara live. Bukan hanya nama Haidar yang dikenal masyarakat, nama SD Muhammadiyah 9 juga ikut terimbas kepopuleran salah satu siswanya.

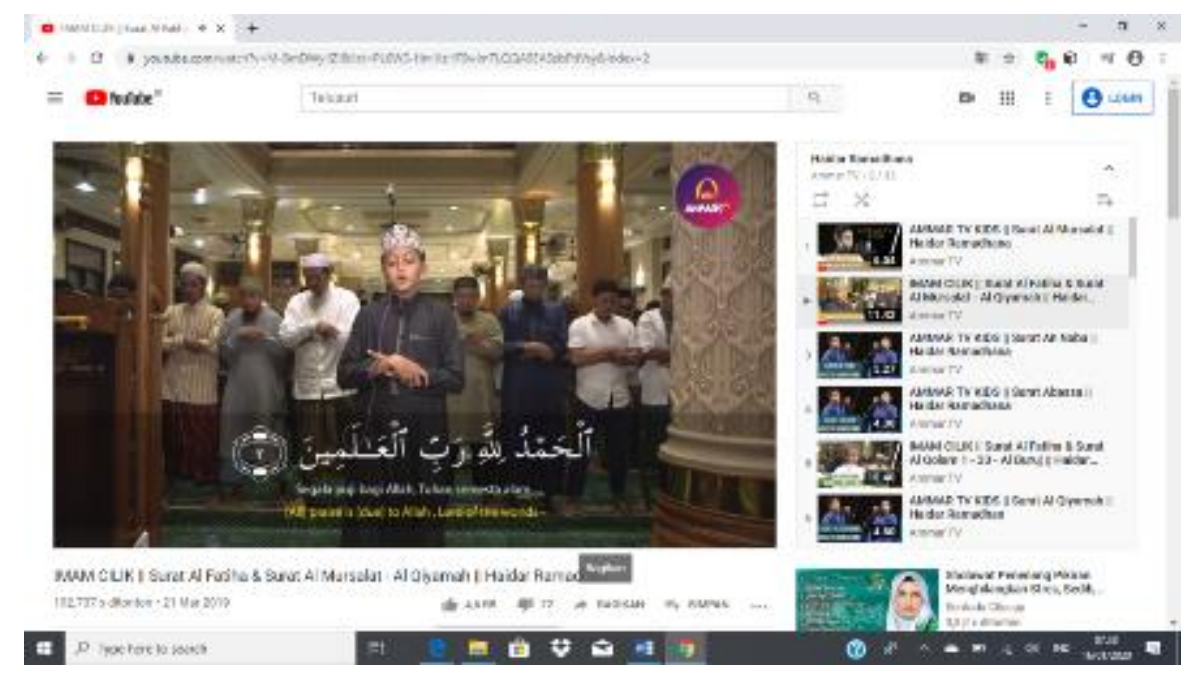

Gambar 4. Youtube Imam Cilik - Haidar Ramadhan 


\section{Jurnal Komunikasi Nusantara}

\section{E-ISSN. 2685-7650}

Vol. 2 No. 1 (2020), pp 17-27

DOI: https://doi.org/10.33366/jkn.v2i1.31

Berbeda dengan tayangan video sebelumnya, pada tayangan di bawah ini memberikan gambaran bahwa aktivitas apapun bisa diunggah di media sosial.

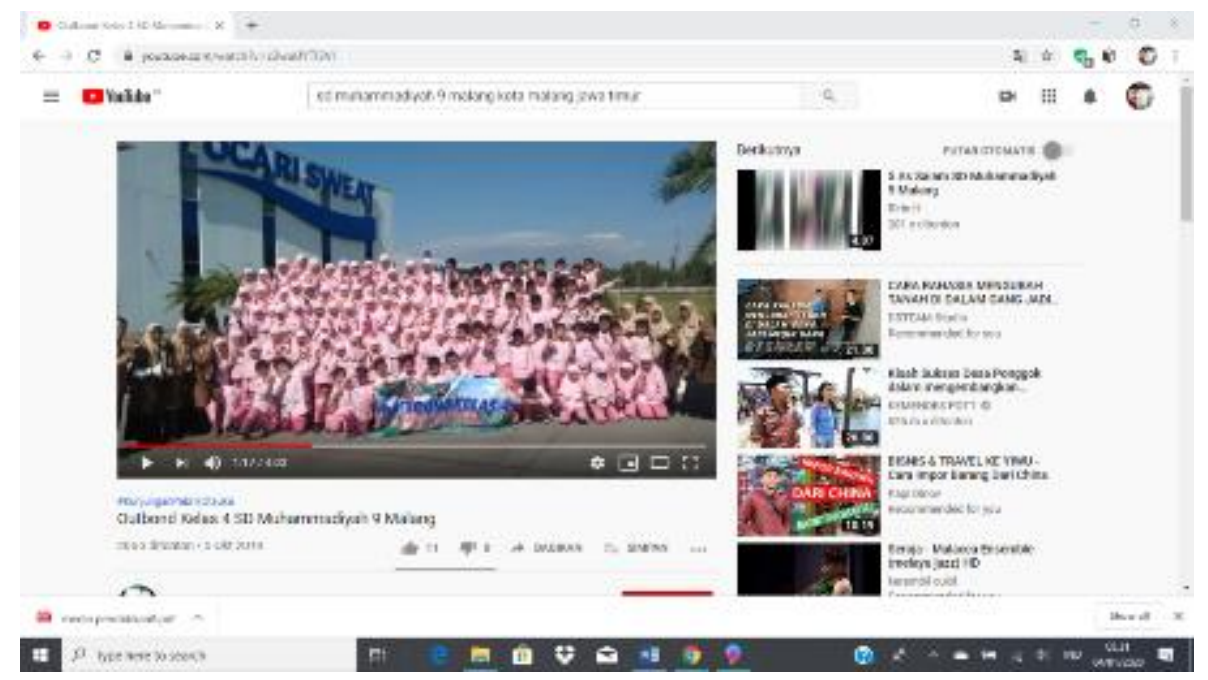

Gambar 5. Youtube Outbound Kelas 4 SD Muhammadiyah 9 Malang

Meskipun sederhana acara kunjungan ke suatu tempat adalah momen yang tak terlupakan. Guru dan siswa diajak sama-sama menikmati acara kunjungan tersebut dan tidak lupa mengabadikan momen tersebut dan mengunggahnya di media sosial. Tidak perlu menunggu berapa follower yang akan menontonnya, yang terpenting mengabadikan sekaligus memberi pembelajaran pada siswa bahwa apa yang mereka lakukan dapat diambil manfaatnya.

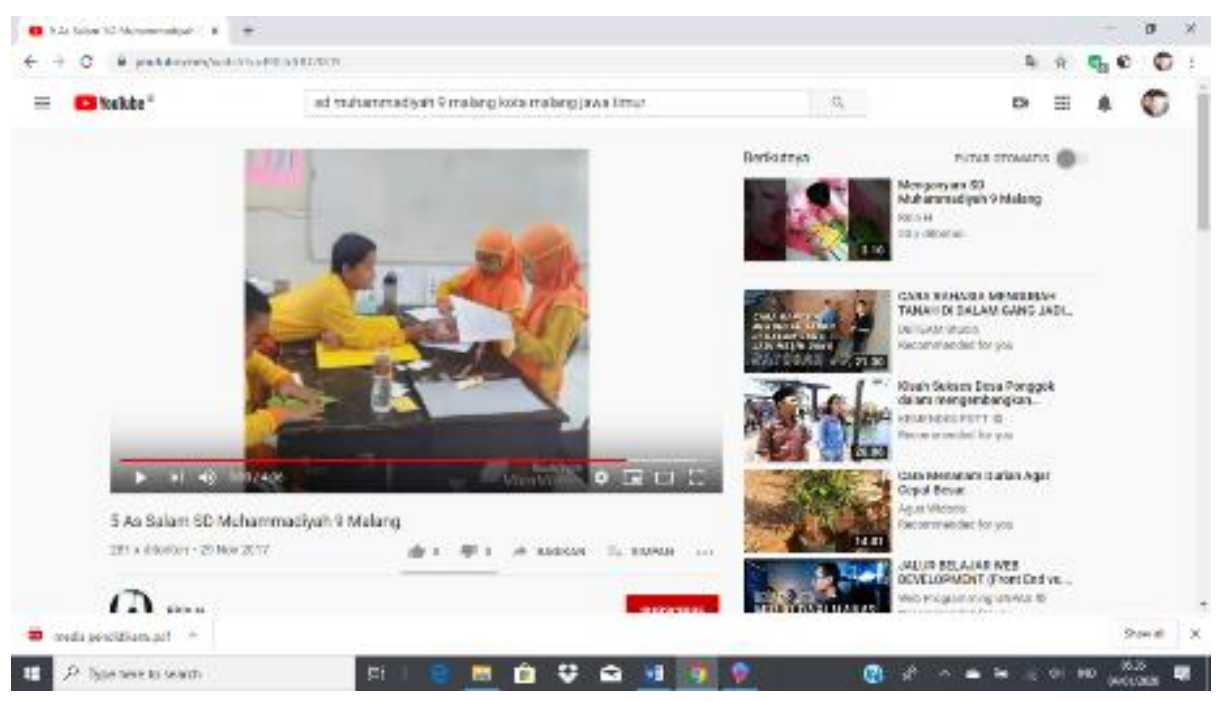

Gambar 6. Youtube 5 As Salam SD Muhammadiyah 9 Malang

Manfaat penggunaan media sosial juga terasa ketika siswa mengunggah proses belajar mengajar di kelas. Aktivitas dikelas tidak luput dari pengabadian momen dan mengunggahnya di media sosial. Keceriaan, kebersamaan, keseriusan, atau kejenakaan akan bercampur baur dalam tayangan yang diunggah. Siswa diharapkan bisa menonton sendiri video-video mereka meski di rumah. Evaluasi diri dapat mereka lakukan di masa saja. Jika di rumah orang tua dapat dimanfaatkan sebgai juri terhadap anak mereka sendiri. Masukan dan kritikan dari orang tua wali murid seringkali 


\section{Jurnal Komunikasi Nusantara}

\section{E-ISSN. 2685-7650}

Vol. 2 No. 1 (2020), pp 17-27

DOI: https://doi.org/10.33366/jkn.v2i1.31

terjadi. Masukan akan dicatat oleh guru yang selanjutnya dipergunakan sebagai bahan pertimbangan atas proses pembelajaran di lain kesempatan. Tidak menutup kemungkinan segala masukan dan kritikan dari luar akan memacu semangat kreatifitas dan imajinasi baru bagi guru dan siswa SD Muhammadiyah 9 Malang.

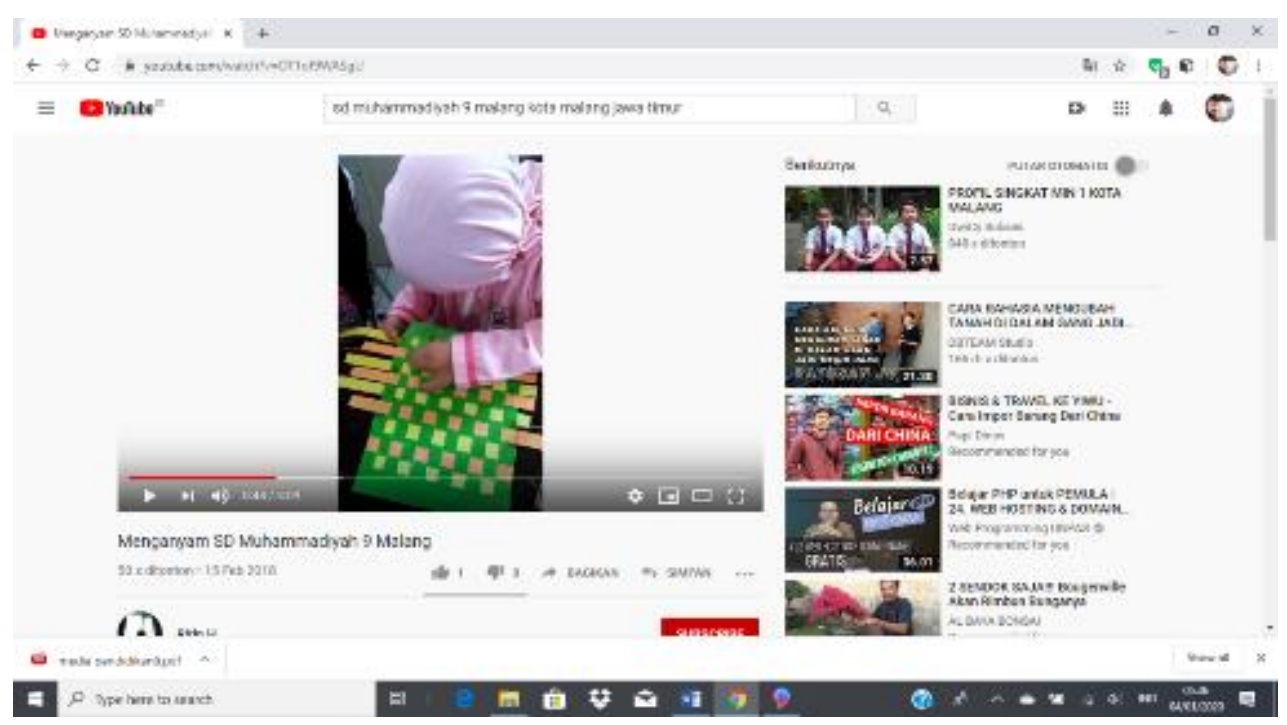

Gambar 7. Youtube Mengayam SD Muhammadiyah 9 Malang

\section{Analisa Data}

Syarat umum berlakunya sebuah budaya adalah terjadinya pembiasaan terhadap suatu model yang diikuti secara temurun. Pembiasaan mengartikan berulangnya suatu tindakan yang sama dari satu person ke person yang lain, terutama diikuti oleh generasi di bawahnya. Meski tidak harus generasi setelahnya, namun tindakan berulang juga berpotensi menularkan tindakan yang sama pada person yang lain pada kesempatan yang lain pula.

Merujuk data-data di atas dalam pembelajaran yang menggunakan media sosial ternyata mampu menelurkan kebiasaan-kebiasaan (baik positif atau negatif) yang dalam istilah kriminologi biasa disebut copycat. Perbuatan menyalin perilaku orang lain yang menurut pandangan sendiri yang bisa ditiru atau diulang. Yang menurut Bruce Joyce et al. $(2016,447)$ dalam bukunya "Models of Teachings",hal ini dekat dengan model personal yang mengindikasikan keyakinannya untuk memperkuat siswa sebagai suatu pribadi adalah bermanfaat ketika tujuan pendidikan berada dalam dirinya sendiri. Model ini menekankan agar siswa mengaktulisasikan diri, lebih afirmatif, dan dikembangkan untuk menuju peningkatan kemampuan pembelajaran. Sehingga model personal ini akan meningkatkan pencapaian akademik dengan merawat jiwa para pembelajar.

Penggunaan media sosial memiliki efektifitas yang sangat tinggi karena keberulangan bisa dilakukan kapan saja, tergantung keinginan si pengguna media sosial. Redandensi dalam belajar merupakan salah satu kunci kemudahan memahami jika terdapat kesalahan atau kesulitan menangkap maksud yang tersembunyi. Media sosial yang tersebar di bebrapa video yang pernah diunggah di laman seperti Youtube berpotensi besar terulang di masa depan iuntuk diperlajri kembali. Selian itu untuk mengingatkan memori, baik bagi si pengunggah atau pemirsa, baik bagi subjek atau objek. Rememorize unggahan di media sosial juga bisa menjadi bahan latihan secara terus menuerus selama belum terhapus dalam memori media sosial itu. Tingkat efektifitas yang tinggi ini juga di dukung oleh semakin canggih dan cepatnya teknologi informasi. Sehingga dengan mudah bagi siapaun untuk 


\section{Jurnal Komunikasi Nusantara}

\section{E-ISSN. 2685-7650}

Vol. 2 No. 1 (2020), pp 17-27

DOI: https://doi.org/10.33366/jkn.v2i1.31

menemukan laman-laman yang diinginkan. Belum lagi proses penyebarluasan konten kepada siapa pun yang membutuhkan.

Mungkin suatu saat pola pembelajaran daring (online) akan menjadi tren baru yang akan diadopsi menjadi salah satu pilihan rasional. Di masa-masa sulit seperti peristiwa pandemi hebat covid-19 adalah contoh kondisi yang memungkinkan berlakunya pola pembelajaran daring. Semua siswa hampir di seluruh dunia dipaksa belajar secara online melalui kanal-kanal yang tersedia. Ketika keadaan tidak memungkinkan untuk berada di luar rumah, satu-satunya cara belajar efektif dan efisien adalah melalui penggunaan media sosial (daring) dengan satu syarat tersedianya jaringan internet dengan kapsitas tertentu untuk menjalankan proses belajar mengajar secara lancar. Namun pola ini juga perlu memperhatikan beberapa aturan agar terhindar dari dampak negatif media sosial. Dan ini perlu penelitian lebih lanjut tentang pengaruh penggunaan media sosial di era pandemi yang berguna untuk menyusun kembali model pembelajaran yang aman dan sehat.

Selain itu pengalaman belajar melalui media sosial menekankan pada sosial system yang mengajak siswa dan guru ikut mengalami dan merasakan peristiwa atau momentum. Bila keadaan ini terus menerus dilakukan akan berubah menjadi kebiasaan. Semua bergantung pada proses yang telah berjalan dalam beberapa waktu. Lalu pembiasaan itu bisa dikatakan sebagai proses pembudayaan baru.

\section{Kesimpulan}

Pembelajaran merupakan proses panjang yang harus dilalui oleh guru dan siswa di sebuah sekolah. Oleh karena itu perlu dikembangkan terus-menerus guna memperoleh hasil yang diinginkan. Dalam kasus SD Muhammadiyah 9 ini , penggunaan media sosial sebagai sarana atau model konsep belajarnya patut diapresiasi. Karena media sosial hari ini sedang ada di puncaknya dikenali oleh masyarakat. Sayang sekali jika tidak bisa memanfaatkan sebaik-baiknya media sosial untuk mendukung proses pembelajaran.

Sekalipun media sosial telah membuat terobosan-terobosan baru yang mungkin di masa depan tidak terduga. Kesiapan SD Muhammadiyah 9 menyambut era digital media yang meninggalkan budaya tradisional akan berujung pada kemampuan siswanya di masa depan. Siswa tidak lagi gagap menghadapi sorotan kamera dimana pun dan kapan pun. Mereka sudah dibekali kemampuan adaptasi secara cepat. Kebiasaan-kebiasaan yang dibangun ketika sekolah di SD Muhammadiyah 9 akan tetap teringat selain sebagai kenangan juga pengetahuan. Selain murah, efektifitas penggunaan media sosial dalam rangka pembelajaran siswa juga perlu dipertimbangkan. Cukup menggunakan gawai yang sekarang ada di tangan hampir semua orang, segala aktivitas yang berkaitan dengan pembelajaran bisa diakses dengan mudah. Tidak ada kata tidak bisa, dan tidak ada kata tertinggal dalam menyesuaikan diri dengan budaya baru pembelajaran di era teknologi informasi.

Catatan kritis yang perlu diperhatikan adalah bijak dalam menggunakan media sosial. Seyogyanya tidak mempergunakan media sosial untuk hal-hal yang negatif. Peran guru dan orang tua mengawasi setiap langkah para siswa memanfaatkan gawai sangat diperlukan. Karena implikasi yang didapatkan akan sangat besar berimbas pada bidang yang lain.

\section{Daftar Pustaka}

Arsyad, A. (2016). Media Pembelajaran. Jakarta: Raja Grafindo Persada.

Arsyad, A. (2007). Media Pembelajaran. Jakarta: Raja Grafindo Persada

Clark, R. C. \& Mayer, R., E. (2008). E-Learning and the science of instruction (second edition). San Francisco: Pfeiffer

Creswell, J.W. (2015). Penelitian Kualitatif dan Desain Riset, Memilih Di antara Lima Pendekatan. Yogyakarta: Pustaka Pelajar. 


\section{Jurnal Komunikasi Nusantara}

E-ISSN. 2685-7650

Vol. 2 No. 1 (2020), pp 17-27

DOI: https://doi.org/10.33366/jkn.v2i1.31

Furhan, A. (2000). Pengantar Penelitian dalam Pendidikan. Surabaya: Usaha Nasional.

Gerlach \& Ely (1971). Teaching \& Media: A Systematic Approach. Second Edition, by V.S. Gerlach \& D.P. Ely, 1980, Boston, MA: Allyn and Bacon. Copyright 1980 by Pearson Education.

Hamalik, Oemar. (2005). Perencanaan Pengajaran Berdasarkan Pendekatan Sistem. Jakarta: PT Bumi Aksara.

Isman, A., Caglar, M., Dabaj, F., Ersozlu, H. (2005). A New Model For The World Of Instructional Design: A New Model. The Turkish Online Journal of Educational Technology - TOJET, 4(3), $33-39$.

Joyce, B., Weil, M., Calhoun, E. (2009). Models of Teaching: Model-Model Pengajaran. Yogyakarta: Pustaka Pelajar.

Moleong, L.J. (2017). Metodologi Penelitian Kualitatif (edisi revisi). Bandung: PT. Remaja Rosdakarya.

Kemendikbud RI. (2014). Permendikbud No. 49 Tahun 2014 tentang Standar Nasional Pendidikan Tinggi. Jakarta: Kemendikbud.

Thut, I.N., Adams, D. (2005). Pola-pola Pendidikan dalam Masyarakat Kontemporer. Yogyakarta: Pustaka Pelajar.

Zendrato, J. (2016). Tingkat Penerapan Rencana Pelaksanaan Pembelajaran Dalam Pelaksanaan Pembelajaran Di Kelas: Suatu Studi Kasus Di SMA Dian Harapan Jakarta. SCHOLARIA: Jurnal Pendidikan dan Kebudayaan, 6(2). 